\title{
IMPLEMENTASI BUDAYA SEKOLAH BERNUANSA ISLAMI DALAM PENDIDIKAN KARAKTER DI MIN I MALANG
}

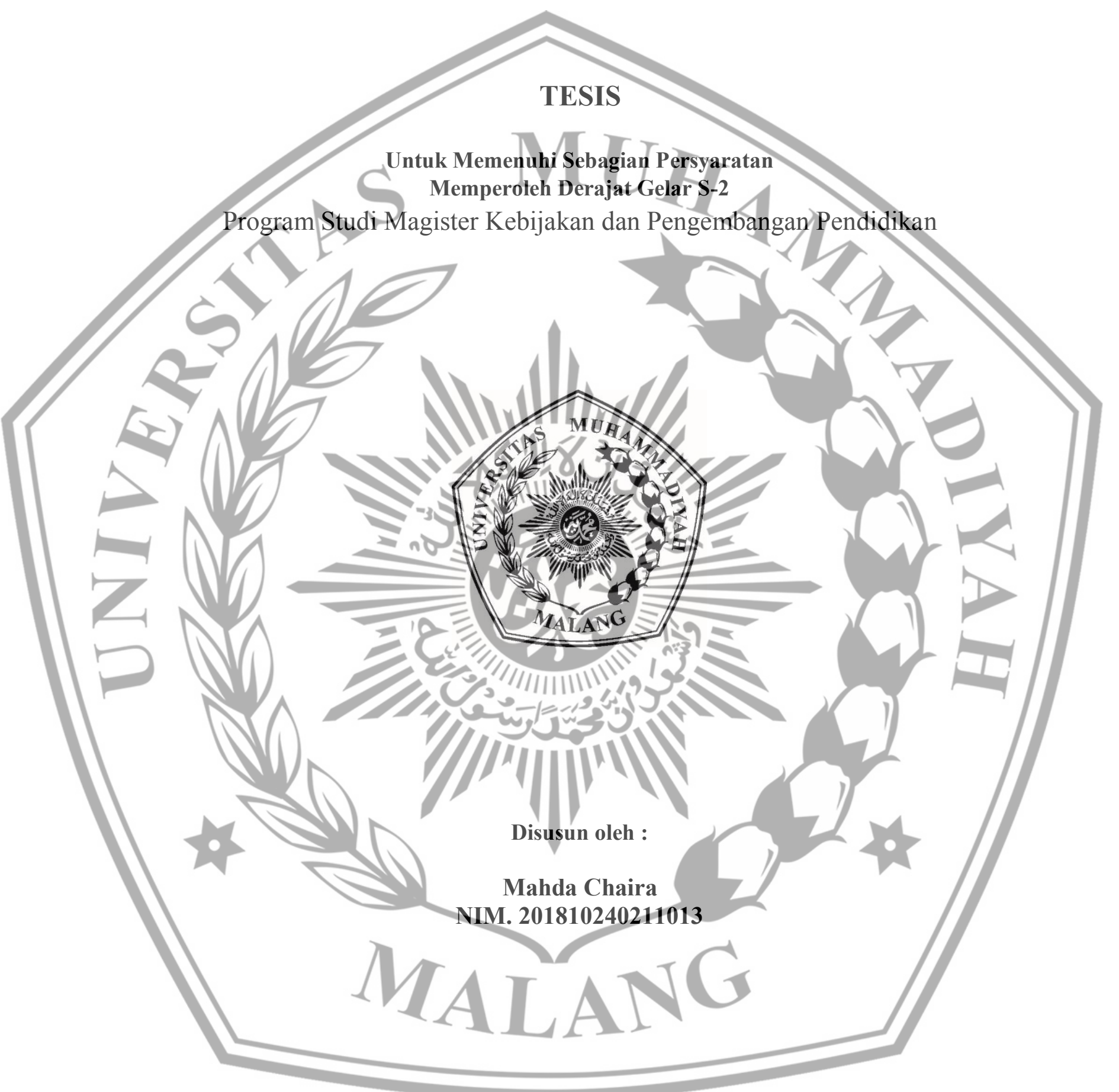

DIREKTORAT PROGRAM PASCASARJANA

UNIVERSITAS MUHAMMADIYAH MALANG 
IMPLEMENTASI BUDAYA SEKOLAH BERNUANSA ISLAMI DALAM PENDIDIKAN KARAKTER DI MIN I MALANG

Diajukan oleh:

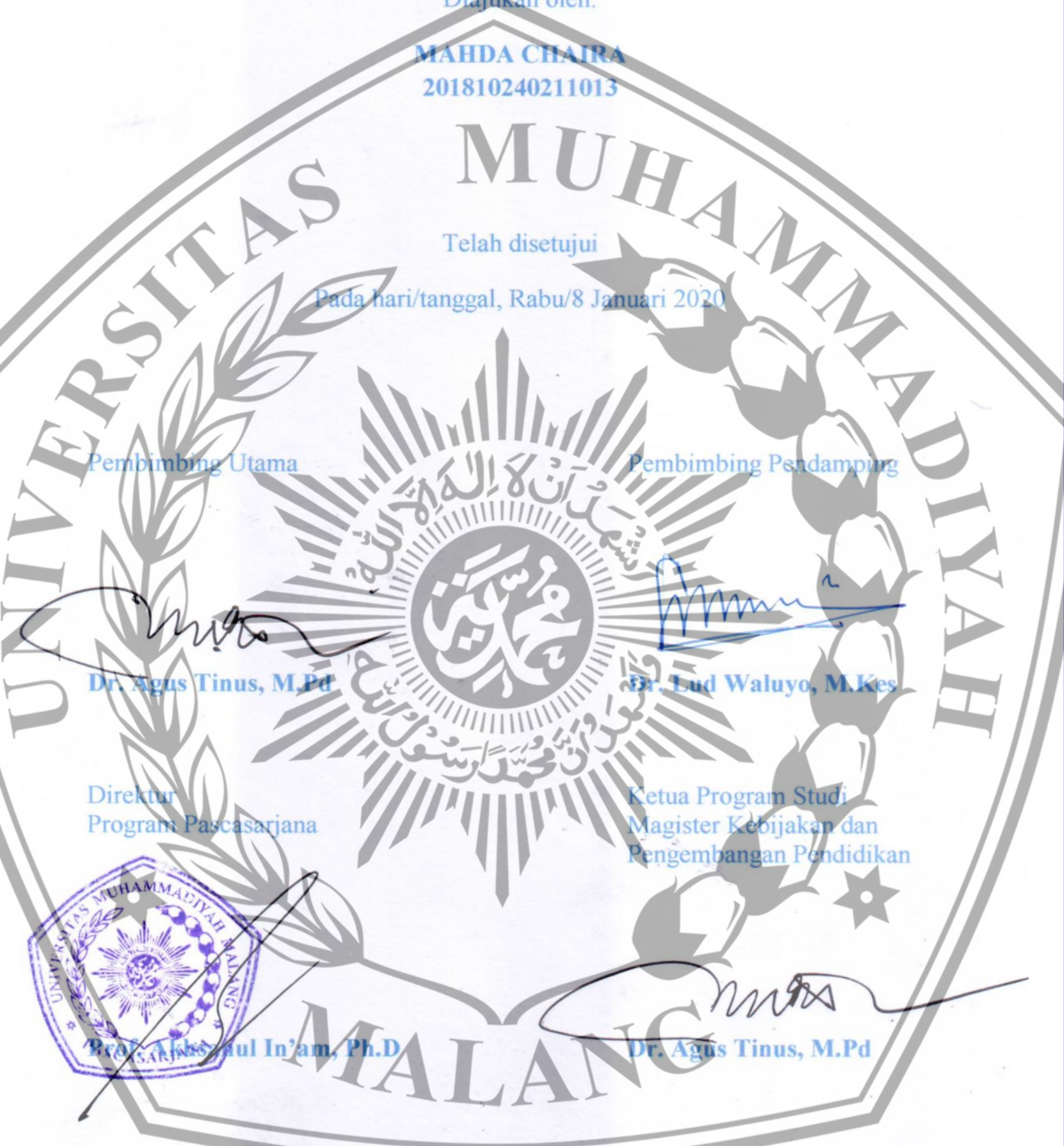




\section{TESIS}

Dipersiapkan dan disusun oleh:

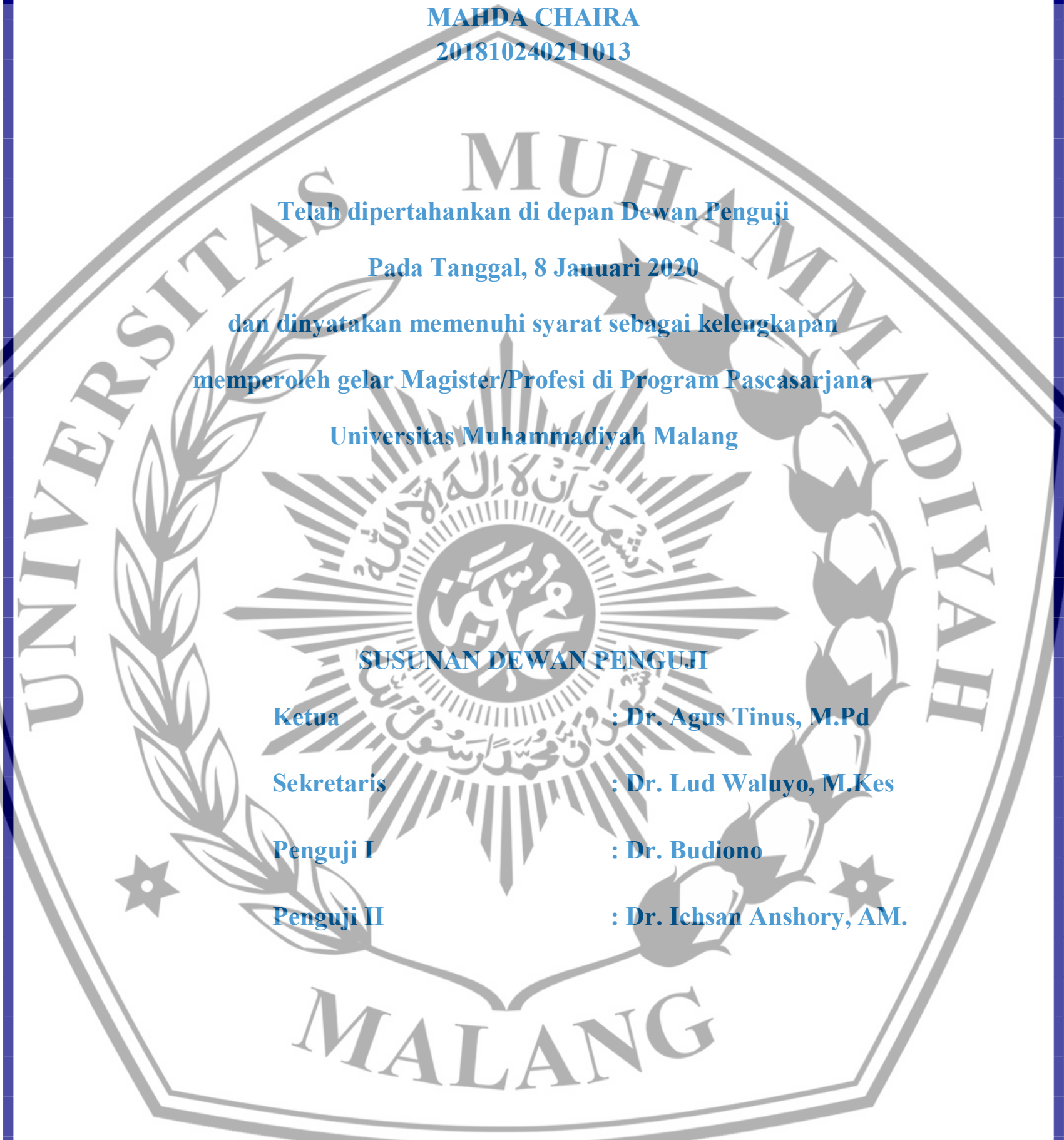




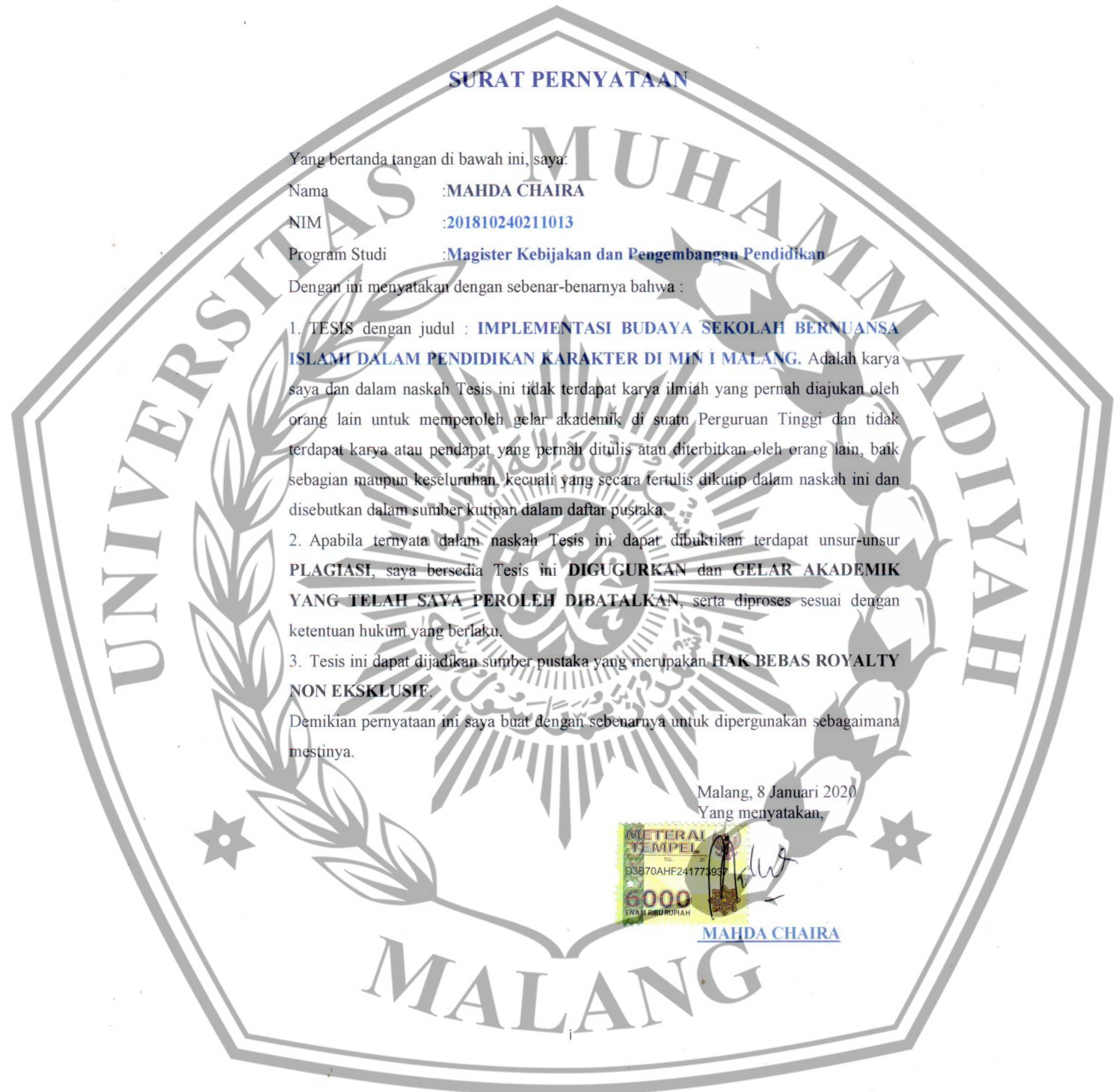




\section{PERSEMBAHAN}

Puji syukur kepada Allah SWT, yang telah memberikan kemudahan dan kelancaran selama menempuh studi hingga proses penyelesaian tugas akhir ini.

Terimakasih untuk semua pihak yang setia memberikan dukungan dan

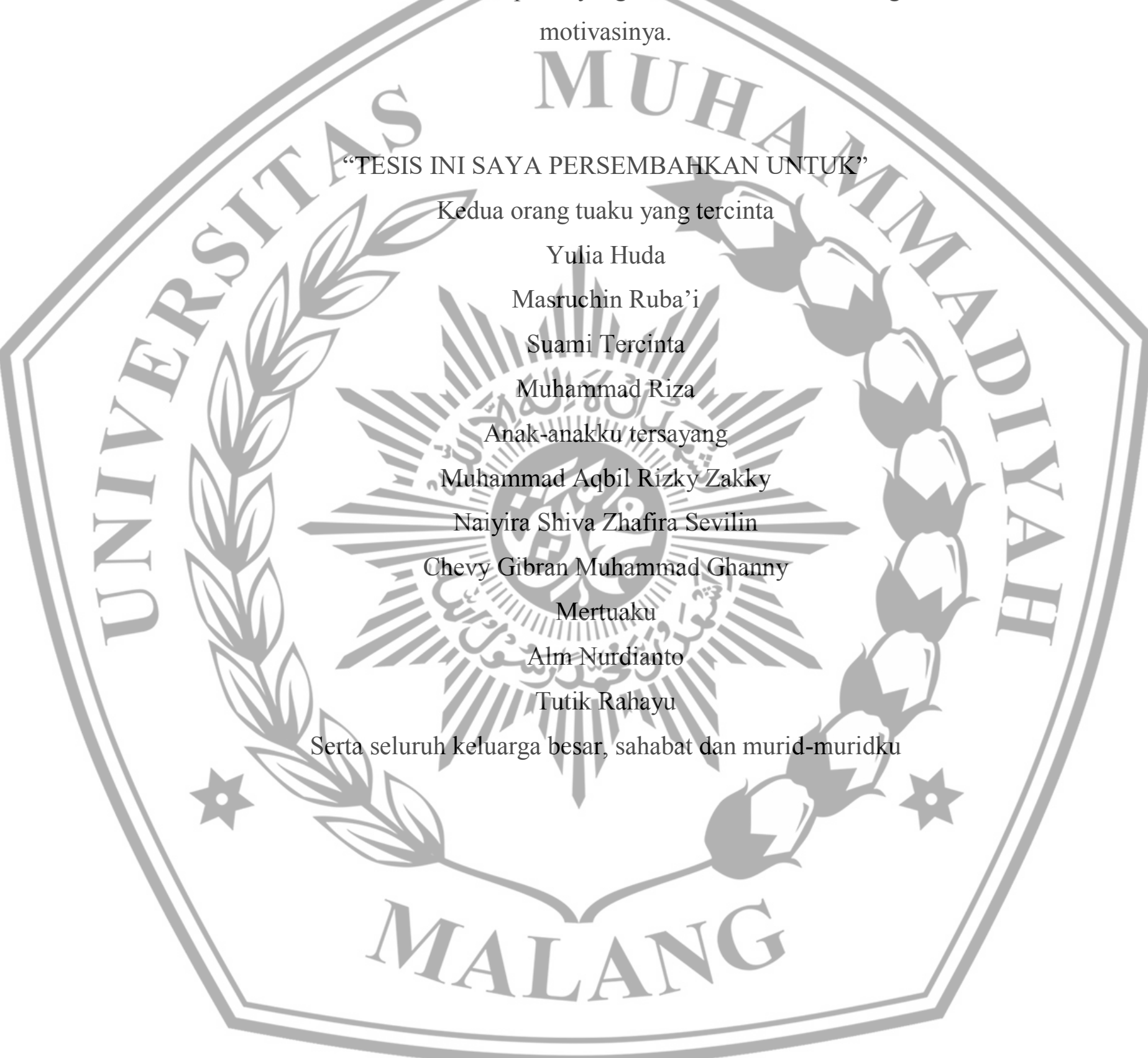




\section{KATA PENGANTAR}

Alhamdulillah, Puji syukur penulis ucapkan kehadirat Allah SWT, atas segala karunia dan ridho-Nya sehingga tesis dengan judul "Implementasi Budaya Sekolah Bernuansa Islami di MIN I Malang" dapat diselesaikan.

Tesis ini disusun untuk memenuhisalah satu persyaratan memperoleh gelar Magister Pendidikan (M.Pd) pada/program/studi Magister Kebijakan dan Pengenbangan Pendidikan.

Penyelesaian Tesis ini tidak terlepas dai petunjuk arahan, bimbingan serta dukungan yang diberikan oleh dosen pembimbing serta bantuan dari berbagai pihak. Oleh karena itu, pada kesempatan ini penulis menyampaikan rasa hormat dan menghaturkan terima kasih yang sebesar-besarnya, kepada:

1. Akhsanul In’am, selaku Direktur/Program Pascasarjana Universitas Muhammadiyah Malang yang telah memberikan perijinan untuk penulis melakukan penelitian.

2. Dr. Agus Tinus, selaku Ketua Program Studi Magister Kebijakan dan Pengembangan Pendidikan Universitas Muhammadiyah Malang yang memberikan kesempatan penulis untuk menulis Tesis, sertal selaku pembimbing 1 yang telah memberikan arahan dan bimbingan kepada penulis sehingga Tesis ini dapat terselesaikan dengan baik.

3. Dr. Lud Waluyo, selaku pembimbing II yang telah memberikan arahan dan bimbingan kepada penulis sehingga Tesis ini dapat terselesaikan dengan baik.

4. Kedua orang tua saya Masruchin Ruba'i dan Yulia Huda yang telah banyak memberikan dukungan, arahan serta do'a nya dalam menyelesaikan Tesis hingga tahap akhir.

5. Suami dan anak-anak saya yang telah banyak memberikan dukungan, serta do'a nya dalam menyelesaikan Tesis hingga tahap akhir.

6. Seluruh dosen Program Studi Magister Kebijakan dan Pengembangan Pendidikan yang telah memberikan ilmu pengetahuan pada penulis selama menjadi mahasiswa. 
7. Kepada semua pihak yang telah membantu yang tidak dapat penulis sebutkan satu persatu.

Dengan keterbatasan pengalaman, ilmu maupun pustaka yang ditinjau, penulis menyadari bahwa tesis ini masih banyak kekurangan dan pengembangan lanjut agar benar benar bermanfaat. Oleh sebab itu, penulis sangat mengharapkan kritik dan saran agar tesis ini lebih sempurna serta sebagai masukan bagi penulis untuk penelitian dan penulisan karya ilmiah di masa yang akan datang. Akhir kata, penulis berharàp tesis ini memberikan manfaat bagi kita semua terutama untuk pengembangàn ilmu pengetahuan yang ramah lingkungan.

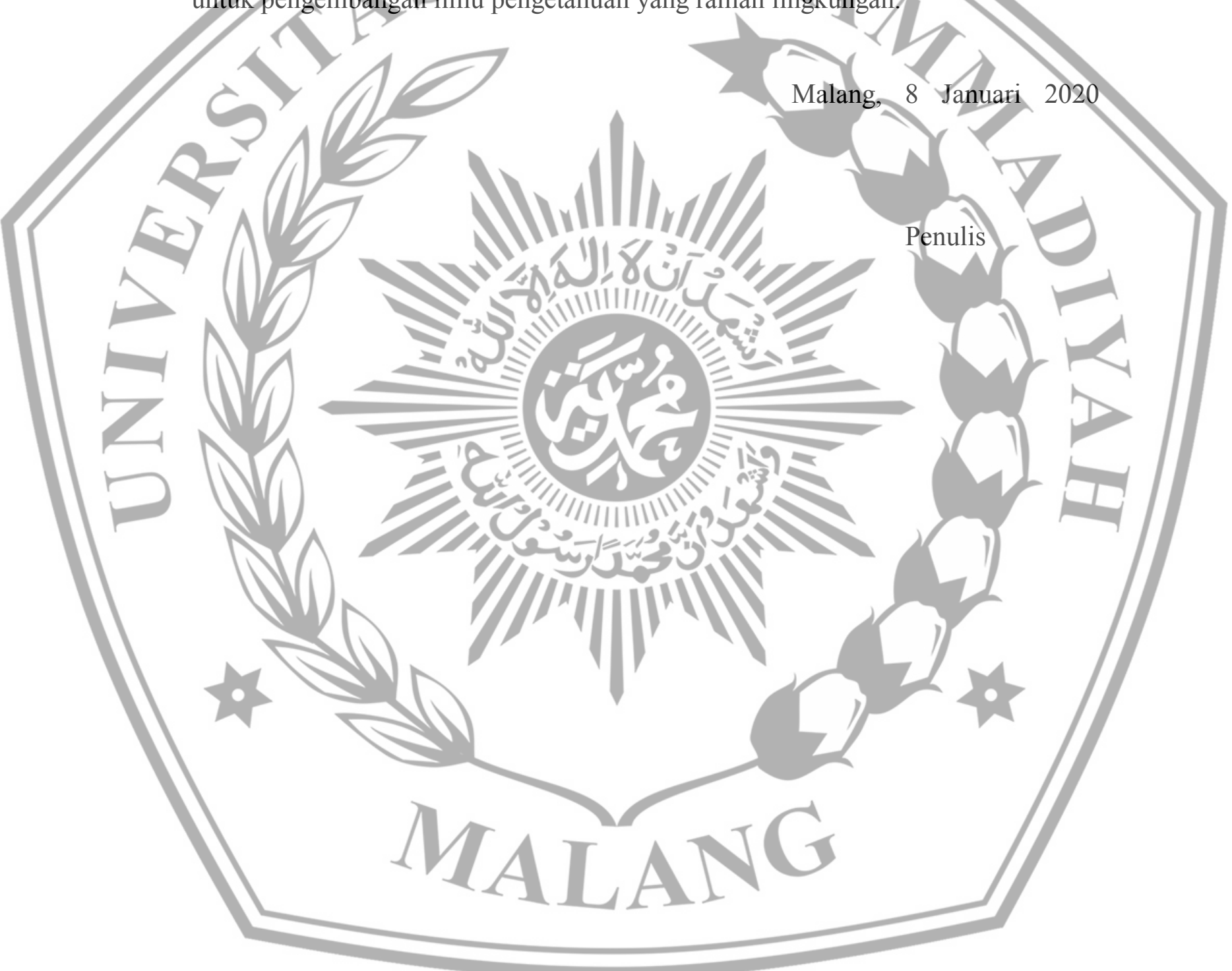




\begin{abstract}
ABSTRAK
\end{abstract}
Chaira, Mahda. 2019. Implementasi Budaya Sekolah Bernuansa Islami dalam Pendidikan Karakter di MIN I Malang. Tesis. Magister Kebijakan dan Pengembangan Pendidikan. Universitas Muhammadiyah Malang. Pembimbing: 1) Dr. Agus Tinus (NIDN. 0021076601); 2) Dr. Lud Waluyo (NIDN. 0005106602). mahdachaira@gmail.com

Tujuan dari penelitian adalah untuk mendeskripsikan implementasi budaya Islami di MIN I Mralang, mendeskripsikan karakter Islami yang dikembangkan di MIN I Malang, mengetahui kendala dalam implementasi budaya Islami di MIN I Malang, dan memaparkan upaya yang dilakukan oleh lembaga sekolah untuk mengatasi kendala-kendata tersebut. Metode penelitian dilakukan dengan deskriptif kualitatif. Pengambilan data dilakukan menggunakan wawancara terstruktur dengan mengambil subjek/guru, kepala sekolah, dan orang tua siswa. Hasil penelitian menunjukkan bahwa implementasi budaya Islami di sekolah diawali dengan dibangunnya sistem yang mengarahkan perilaku siswa yang berkarakter Islami melalui pembiasaan perilaku Islami. Kemudian ditunjang dengan pelaksanaan mengaji, 'kultum, dan hafalan Al-Qur'an pada lima belas menit pertama sebelum jam masuk sekolah setiap harinya. Pelaksanaan shalat dhuha, shalat dhuhur, shalatojumat, l dabis/ keputrian di sekolah. Kendala dari pembasaan budaya Islami di sekolah adalah pembiasaan orang tua yang kadang tidak sejalan dan cara mengatasinya adalah dergan membuat grup Whatsapp bagi orang tua murid.

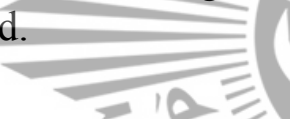

20
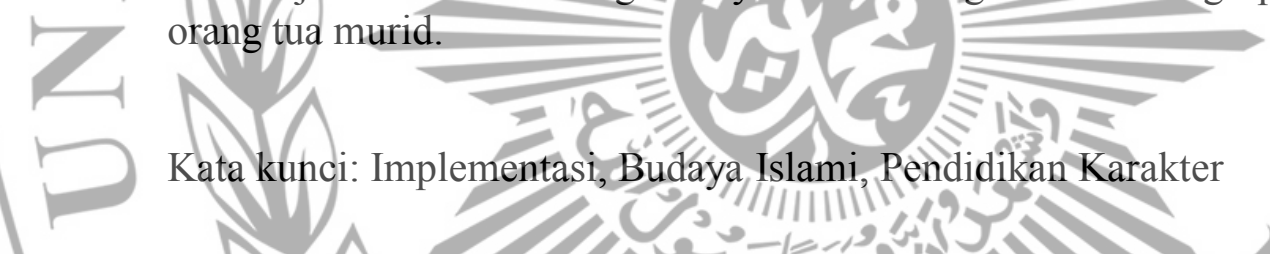

Kata kunci: Implementasi, Budaya, Islami, Pendidikan Karakter

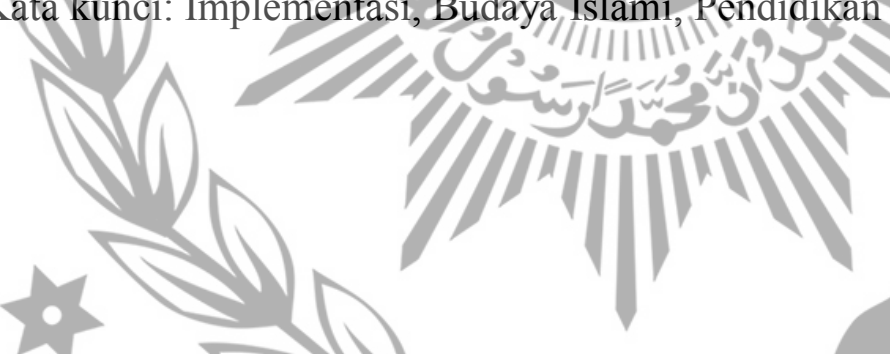




\section{ABSTRACT}

Chaira, Mahda. 2019. Implementation of Islamic Culture Schools in Character Education in MIN I Malang. Thesis. Masters in Education Policy and Development. University of Muhammadiyah Malang. Supervisor: 1) Dr. Agus Tinus (NIDN. 0021076601); 2) Dr. Lud Waluyo (NIDN. 0005106602). mahdachaira@gmail.com

The purpose of the research is to describe the implementation of Islamic culture in MIN I Malang, describe the Islamic character developed in MIN I Malang, identify the obstacles in the implementation of Islamic culture in MIN I Malang, and describe the efforts made by school institutions to overcome these obstacles. The research method was conducted using descriptive qualitative. Data is collected using structured interviews by taking the subject of teachers, school principals, and parents of students. The results show that the implementation of Islamic culture in schools begins with the construction of a system that directs the behavior/ of students with Islamic character through the habituation of Islamic behavior. Then supported by the implementation of the Koran, Kultum, and memorization of the Qur'an in the first fifteen minutes before school hours every day. Duha prayer, Dhuhr prayer, Friday prayer, and princess in school. The obstacle to developing Islamic culture in/schools is the habit of parents who are sometimes not in line and the way to overcome them is by creating a Whatsapp group for students' parents.

Keywords: Implementation, Isłamic Culture, Character Education
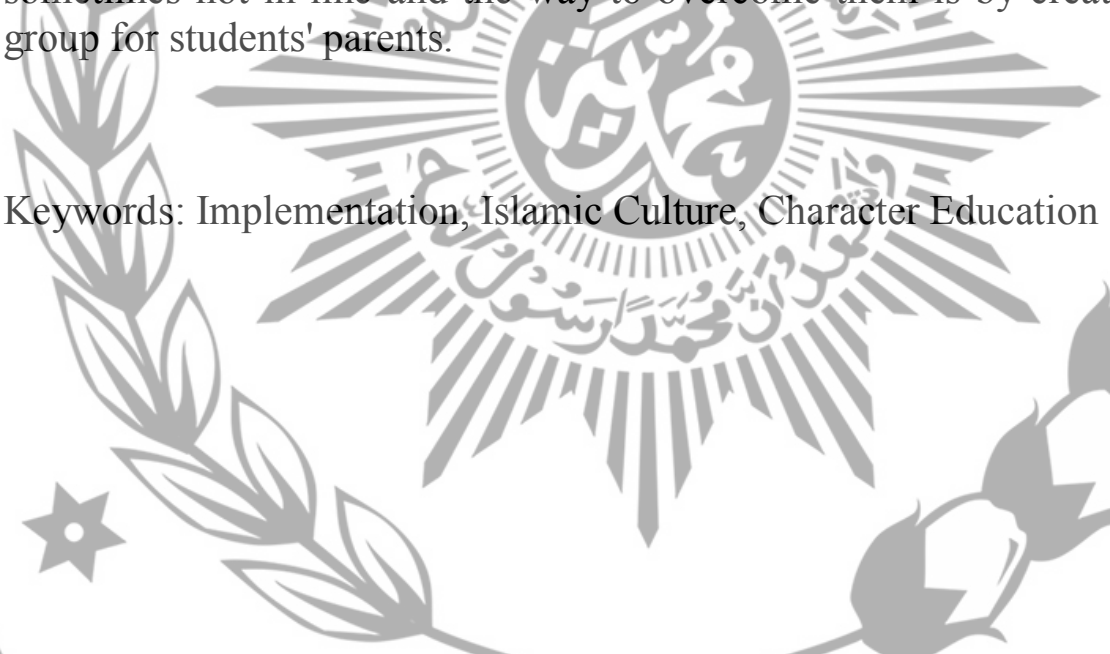


\section{DAFTAR ISI}

\section{Halaman Judul}

Surat Pernyataan ........................................................................... i

Persembahan ....................................................................... ii

Kata Pengantar .....................................................................

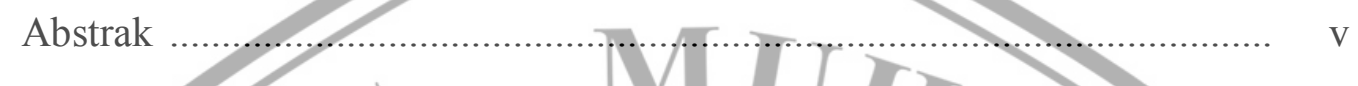

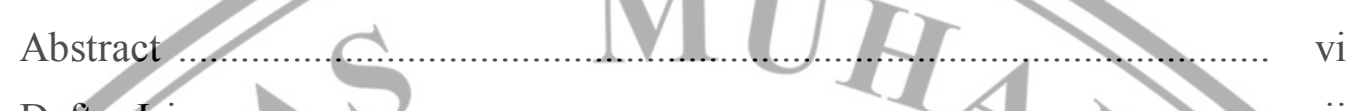

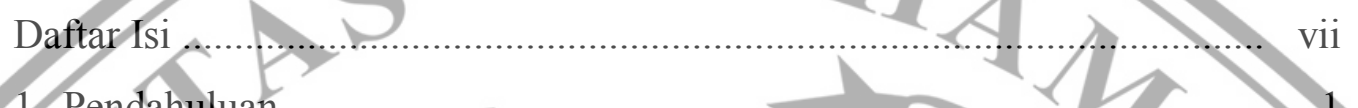

1. Pendahuluan

2. Kajian Teorj...

2.1 Budaya Sekolah Nuansa Islami.....

2.2 Pendidikan Karakter..

2.3 Implementasi Budaya Sekolah Nuansa Islami

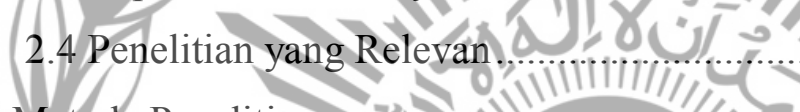

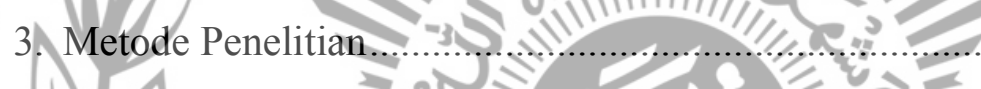

3.1. Pendekatan dan Jenis Penelitian.

3.2 Lokasi Penelitian.............

3.3 Anstrumen Penelitian

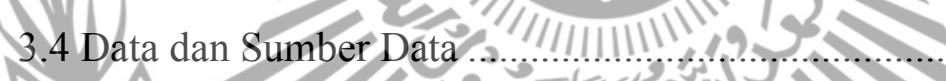

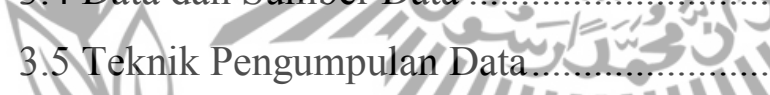

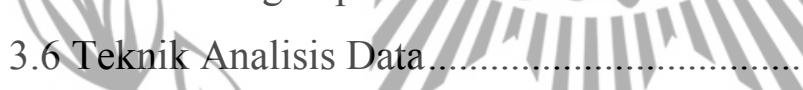

3.7 Pemeriksaan Keabsahan Data.

4. Hasil Penelitian

4.1 Implementasi Budaya Islami di MIN I Malang ........

4.2 Karakter Islami yang Dikembangkan di MIN I Malang

4.3 Kendala dalam/mplementasi Budaya Islami di MIN I Malang ..

4.4 Upaya yang Dilakukan oleh Lembaga Sekolah untuk Mengatasi

Kendala ........................................................................... 21

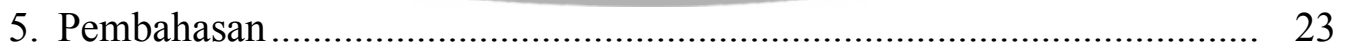

5.1 Implementasi Budaya Islami di MIN I Malang ............................ 23 
5.2 Karakter Islami yang Dikembangkan di MIN I Malang

5.3 Kendala dalam Implementasi Budaya Islami di MIN I Malang .... 25

\subsection{Upaya yang Dilakukan oleh Lembaga Sekolah untuk}

Mengatasi Kendala............................................................... 26

6. Simpulan dan Saran ................................................................. 27

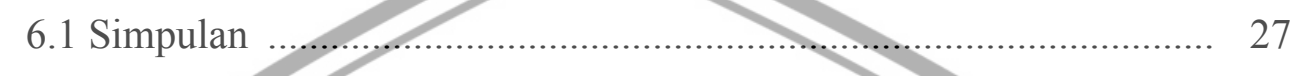

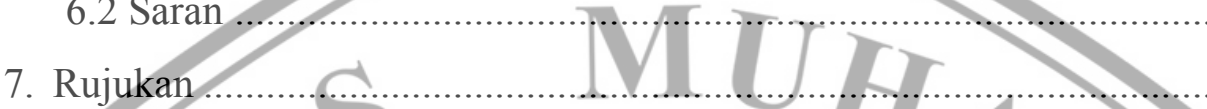

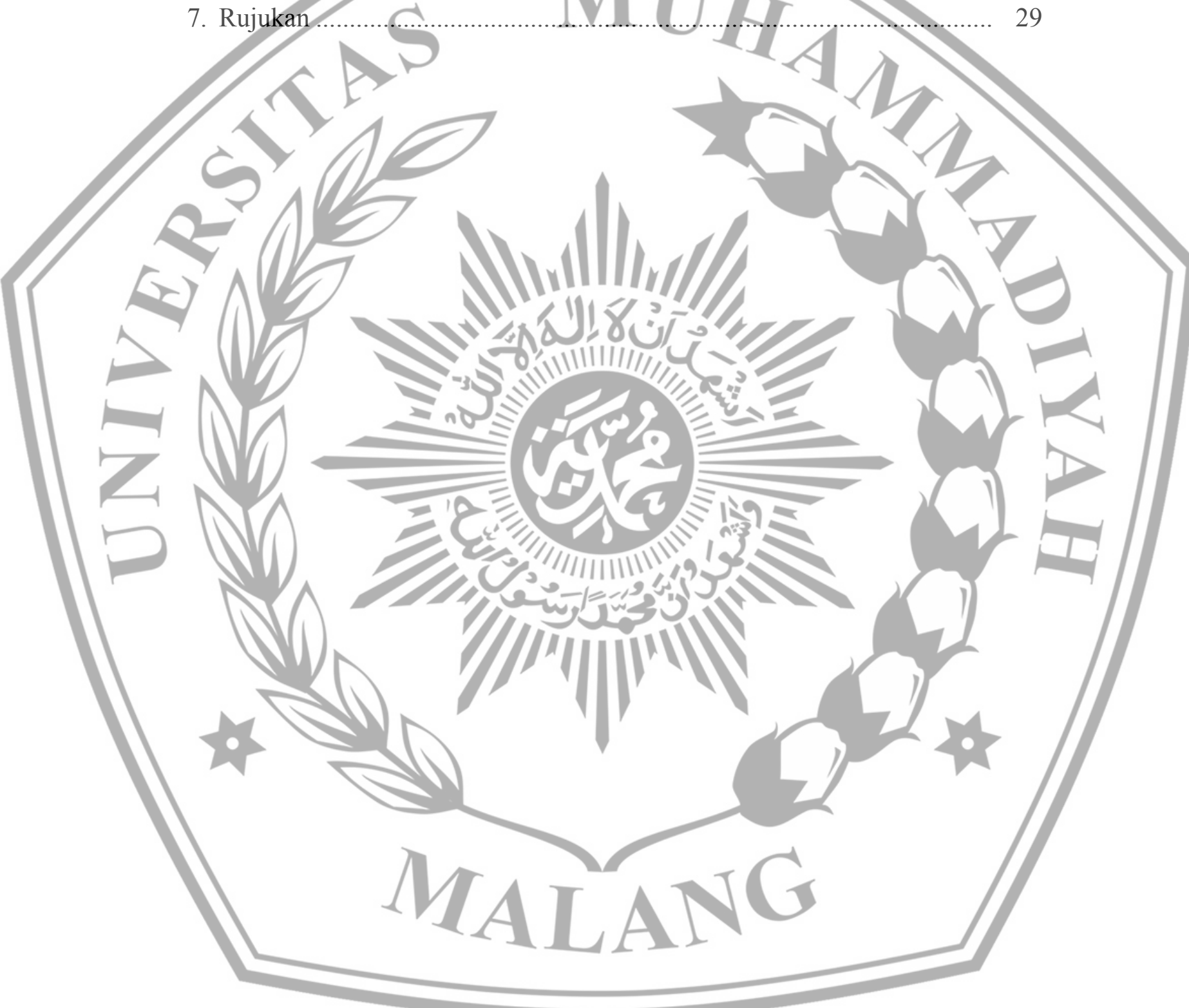


Tesis (Mahda Chaira) 3

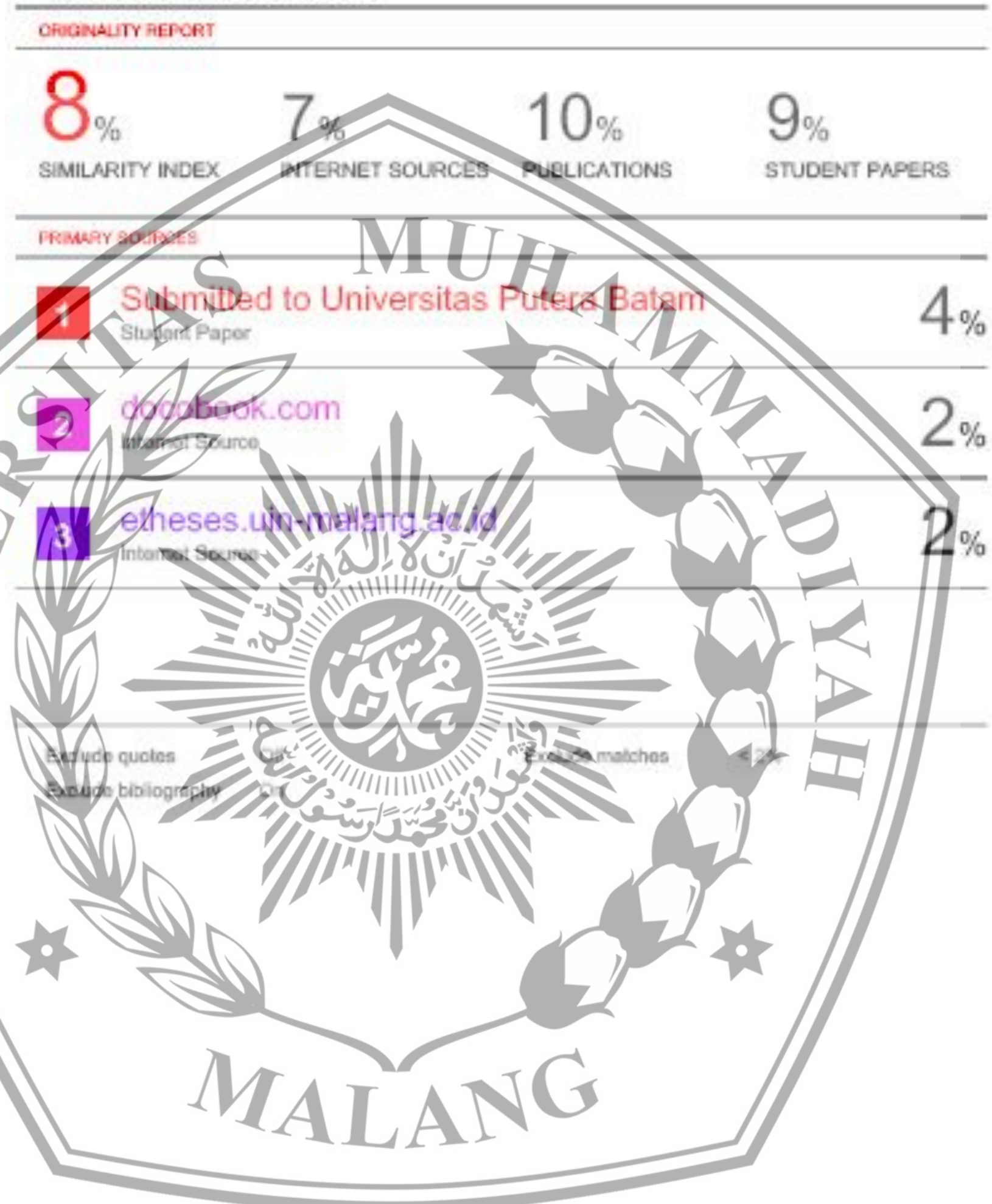

